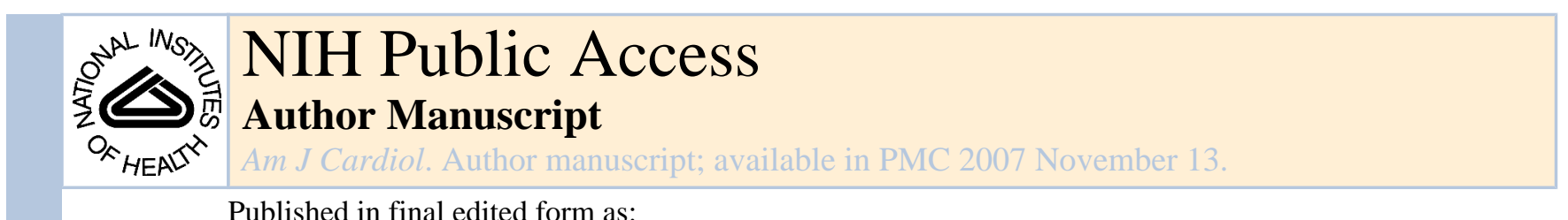

Published in final edited form as:

Am J Cardiol. 2007 October 15; 100(8): 1329.

\title{
Statins and Vitamin D
}

John F. Aloia, M.D., Melissa Li-Ng, M.D., and Simcha Pollack, Ph.D. Mineola, NY 11501

In the recent article by Pérez-Castrillón et al.[1], the authors found that atorvastatin therapy for 12 months significantly increased 25-hydroxyvitamin D (25-OHD) levels in patients with acute ischemic heart disease. We found a similar association between statin use and 25-OHD levels in a vitamin D3 supplementation trial that we conducted [2]. The design and primary results of the study have been published and summarized here. In brief, we conducted a 3-year randomized controlled trial to test the hypothesis that vitamin D3 supplementation would prevent bone loss in calcium-replete, African-American postmenopausal women. Participants received either $20 \mathrm{mcg} / \mathrm{d}$ ( $800 \mathrm{IU}$ ) of vitamin D3 or placebo. After 2 years, the vitamin D3 dose was increased to $50 \mathrm{mcg} / \mathrm{d}$ (2000 IU) in the active group. The study was approved by the Institutional Review Board of Winthrop-University Hospital.

A total of 208 women were randomized to receive vitamin $\mathrm{D} 3(\mathrm{n}=104)$ or placebo $(\mathrm{n}=104) .51$ women were on statins. At baseline, the subjects on statins had a significantly higher 25-OHD level than the subjects who were not on statins $(51.2 \pm 20.1 \mathrm{nmol} / \mathrm{L}$ versus $43.2 \pm 18.0 \mathrm{nmol} /$ $\mathrm{L}$ respectively, $\mathrm{p}=0.008$ ). This was also true when averaging 25 -OHD levels across the 3 -year study period and looking at active and placebo patients separately. 185 subjects had follow-up 25-OHD levels drawn every 6 months during the study. Higher levels were seen in the statin use subgroup whether they were on placebo or active vitamin D (Figure 1). There was no interaction seen between vitamin $\mathrm{D}$ use and statin use, i.e. the impacts are additive $(\mathrm{p}=0.5502)$. This significant difference is comparable to the increase in 25-OHD levels seen in PérezCastrillón's study ( $41 \pm 19$ versus $47 \pm 19 \mathrm{nmol} / \mathrm{L}, \mathrm{p}=0.003)$ [1]. Although Pérez-Castrillón et al found a statistically significant relation between total cholesterol and 25-OHD ( $\mathrm{r}=0.277$, $\mathrm{p}=0.002$ ), we did not find a significant relation between total cholesterol and 25-OHD in our study population.

A recent meta-analysis found that statin use was associated with fewer hip fractures (OR 0.60, 95\% CI $0.45-0.78$ ) and improved hip bone mineral density [3]. In-vitro studies reveal that statins induce osteoblast differentiation [4] and inhibit osteoclast formation [5], thus promoting bone formation. Perhaps one of the ways in which statins reduce fracture risk is by increasing 25-OHD levels. Few studies have looked at levels of vitamin D metabolites and statin use and they offer conflicting results [6-9]. There was concern when statins were first introduced that they would impair the formation of steroids dependent on the cholesterol synthetic pathway but it has been shown that vitamin D synthesis remains normal [10]. The mechanism by which statins increase vitamin D levels is not clear. Dedicated randomized controlled trials investigating statin therapy and vitamin $\mathrm{D}$ are needed.

\section{References}

1. Pérez-Castrillón JL, et al. Effects of atorvastatin on vitamin D levels in patients with acute ischemic heart disease. Am J Cardiol 2007;99:903-905. [PubMed: 17398180]

Publisher's Disclaimer: This is a PDF file of an unedited manuscript that has been accepted for publication. As a service to our customers we are providing this early version of the manuscript. The manuscript will undergo copyediting, typesetting, and review of the resulting proof before it is published in its final citable form. Please note that during the production process errors may be discovered which could affect the content, and all legal disclaimers that apply to the journal pertain. 
2. Aloia JF, Talwar SA, et al. A randomized controlled trial of vitamin D3 supplementation in African American women. Arch Intern Med 2005;165:1618-1623. [PubMed: 16043680]

3. Hatzigeorgiou C, Jackson JL. Hydroxymethylglutaryl-coenzyme A reductase inhibitors and osteoporosis: a meta-analysis. Osteoporos Int 2005;16:990-998. [PubMed: 15744453]

4. Maeda T, et al. Induction of osteoblast differentiation indices by statins in MC3T3-E1 cells. J Cell Biochem 2004;92:458-471. [PubMed: 15156558]

5. Kaji H, Kanatani M, Sugimoto T, Chihara K. Statins modulate the levels of osteoprotegerin/receptor activator of NFKB ligand mRNA in mouse bone-cell cultures. Horm Metab Res 2005;37:589-592. [PubMed: 16278780]

6. Wilczek H, et al. Monitoring plasma levels of vitamin D metabolites in simvastatin therapy in patients with familial hypercholesterolemia. Cas Lek Cesk (Czeck) 1994;133:727-729.

7. Wilczek J, et al. Iatropathogenic effect of mevacor on vitamin D metabolism. Cas Lek Cesk (Czeck) 1989;128:1254-1256.

8. Montagnini M, et al. Effects of pravastatin treatment on vitamin D metabolites. Clin Ther 1994;16:824829. [PubMed: 7859242]

9. Ismail $\mathrm{F}$, et al. Effects of pravastatin and cholestyramine on circulating levels of parathyroid hormone and vitamin D metabolites. Clin Ther 1990;12:427-430. [PubMed: 2125243]

10. Dobs AS, Levine MA, Margolis S. Effects of pravastatin, a new HMG-CoA reductase inhibitor, on vitamin D synthesis in man. Metabolism 1991;40:524-528. [PubMed: 1902546] 


\begin{tabular}{|l|l|l|l|}
\hline Statin & Active/Placebo & $\mathrm{N}$ & $\begin{array}{l}\text { Mean 25-OHD } \\
(\mathrm{nmol} / \mathrm{L})\end{array}$ \\
\hline \multirow{3}{*}{ No statin } & Active & 64 & $65.9 \pm 20.6^{*}$ \\
\cline { 2 - 4 } & Placebo & 72 & $38.4 \pm 12.8^{*}$ \\
\hline On statin & Active & 29 & $74.0 \pm 18.3^{*}$ \\
\cline { 2 - 4 } & Placebo & 20 & $50.0 \pm 17.7^{*}$ \\
\hline
\end{tabular}

$* \mathrm{p}=0.0009$ when comparing 25-OHD levels between no statin group and statin use group.

Figure 1.

Mean 25-hydroxyvitamin D levels by statin use and treatment group 